\title{
ANALISIS ARUS DAN GELOMBANG PERAIRAN BATU BELANDE GILI ASAHAN DESA BATU PUTIH KECAMATAN SEKOTONG LOMBOK BARAT
}

\author{
Sukuryadi \\ Dosen Program Studi Pendidikan Geografi, Universitas Muhammadiyah Mataram \\ Email : Syukur_y80@yahoo.com
}

\begin{abstract}
ABSTRAK
Salah satu penyebab terjadinya akresi dan rekresi pantai adalah gelombang. Gelombang yang memecah di pantai merupakan penyebab utama proses erosi dan akresi (pengendapan garis pantai) pada saat gelombang mendekati pantai, gelombang mulai bergesekan dengan dasar laut dan menyebabkan pecahnya gelombang di pantai. Hal ini menyebabkan terjadinya turbulensi yang kemudian membawa material dari dasar pantai atau menyebabkan terkikisnya bukit-bukit pasir (sand dunes) di pantai. Gelombang yang memecah pantai merupakan penyebab utama proses erosi dan akresi (pengendapan) garis pantai. Adapun tujuan penelitian ini adalah untuk menganalisis arus dan gelombang perairan dengan prinsip kerja waves buoys di Gili Asahan Desa Batu Putih Kecamatan Sekotong Lombok Barat. Pengambilan data lapangan dilakukan di sekitar perairan Batu Belande Gili Asahan melalui metode survey dan pemetaan dan dilanjutkan dengan analisis pengolahan data dilakukan dengan bantuan software modeling. Hasil analisa data lapangan pada pengukuran arus menunjukkan bahwa kecepatan arus rata-rata pada perairan di gili Asahan adalah $0.0045 \mathrm{~m} /$ det (sebelum ombak pecah) dan $0.0228 \mathrm{~m} /$ det (setelah ombak pecah) dengan arah yang relatif sama yaitu arah barat daya condong arah selatan atau sejajar dengan pantai. Kecepatan arus berkisar antara $0-0,63 \mathrm{~m} /$ det pada titik sebelum ombak pecah dan $0-0.557 \mathrm{~m} /$ det pada titik setelah ombak pecah. Data ini menunjukkan bahwa kecepatan arus di lokasi dikategorikan memiliki kecepatan arus lemah hingga sedang, hal ini sesuai dengan pendapat Djurdjani (1998) bahwa kecepatan arus dikategorikan lemah jika kecepatannya $<0,4 \mathrm{~m} /$ det, Sedang jika kecepatannya 0,4 - 1m/det dan Kuat jika kecepatannya $>1 \mathrm{~m} /$ det. Hasil analisis pengukuran gelombang didapatkan bahwa tinggi gelombang signifikan $\left(\mathrm{H}_{1 / 3}\right)$ pada lokasi penelitian adalah $0.019 \mathrm{~m}$ pada titik sebelum ombak pecah dan $0.0072 \mathrm{~m}$ pada titik setelah ombak pecah, dengan demikian keadaan gelombang signifikan dilokasi dikategrikan tenang hal ini didukung oleh pernyataan Djurdjani (1998) yang mengatakan bahwa Gelombang dikategorikan tenang jika tingginya $<0,20 \mathrm{~m}$, Sedang jika tingginya 0,2 - 0,50 $\mathrm{m}$, dan besar jika tingginya $>0,50$. Adapun kecepatan gelombang sebelum dan sesudah ombak pecah pada musim angin timur dan barat masing-masing $5,48 \mathrm{~m} / \mathrm{s}, 2,74 \mathrm{~m} / \mathrm{s}$ dan $5,48 \mathrm{~m} / \mathrm{s}$ hal ini menunjukkan bahwa semakin mendekati pantai maka kecepatan gelombang semakin melemah seiring dengan kedalaman perairan yang semakin dangkal, sedangkan energi gelombang sebelum dan sesudah ombak pecah pada musim angin timur dan barat masing-masing adalah $0,460 \mathrm{~N} / \mathrm{m}^{2}, 0,066 \mathrm{~N} / \mathrm{m}^{2}$ dan $1965,172 \mathrm{~N} / \mathrm{m}^{2}$
\end{abstract}

Kata kunci: Arus, Gelombang, Perairan

\section{PENDAHULUAN}

Wilayah pesisir merupakan ekosistem yang unik mengingat pada kawasan ini terjadi interaksi antara ekosistem daratan dan ekosistem lautan. Berbagai aktifitas manusia dalam berbagai bidang kehidupan akhir-akhir ini banyak dilakukan di kawasan pesisir sehingga apabila tidak terkendali, aktifitas ini secara ekologis dapat menyebabkan kerusakan sumberdaya alam dan lingkungan yang akan berakibat pada penurunan kualitas daya dukung lingkungan di kawasan tersebut (Sachoemar dan Alian, 1983). Pantai merupakan bentuk geomorfologi yang dinamis, terutama diakibatkan oleh tenaga eksogen seperti abrasi dan akresi. Secara umum proses abrasi awalnya terjadi pada bagian pantai yang terkena air laut hingga membentuk suatu lekukan lapisan batu, tanah dan tanaman yang terletak diatas lekukan tersebut secara bertahap akan melapuk lalu runtuh, akibatnya pantai perlahanlahan akan landai dan mundur ke arah daratan. Materi yang terkikis itu diangkut oleh air laut dan diendapkan di bagian-bagian yang landai.

Salah satu penyebab terjadinya akresi dan rekresi pantai adalah gelombang. Gelombang yang memecah di pantai merupakan penyebab utama proses erosi dan akresi (pengendapan garis pantai) pada saat gelombang mendekati pantai, gelombang mulai 
bergesekan dengan dasar laut dan menyebabkan pecahnya gelombang di pantai. $\mathrm{Hal}$ ini menyebabkan terjadinya turbulensi yang kemudian membawa material dari dasar pantai atau menyebabkan terkikisnya bukit-bukit pasir (sand dunes) di pantai.

Gelombang yang memecah pantai merupakan penyebab utama proses erosi dan akresi (pengendapan) garis pantai. Pada saat gelombang memecah bibir pantai, terjadi run-up, kemudian surut kembali ke laut dan membawa material/sedimen di sekitar pantai. Sedimen ini disebut lithoral drift, sebahagian besar gelombang datang dengan membentuk sudut tertentu terhadap garis pantai (longshore current) dengan menggerakkan lithoral drift atau sedimen sekitar garis pantai dalam bentuk zig zag sebagai akibat datang dan surutnya gelombang laut (Pratikto, dkk., 1997).

Gelombang yang mendekati pantai akan mengalami pembiasan (refraction) dan akan memusat (convergence) jika mendekati semenanjung, atau menyebar (divergence) jika menemui cekungan. Disamping itu, gelombang yang menuju perairan dangkal akan mengalami spilling, plunging, collapsing atau surging. Ombak merupakan salah satu penyebab yang berperan dalam pembentukan pantai. Ombak yang terjadi di laut dalam pada umumnya tidak berpengaruh terhadap dasar laut dan sedimen yang terdapat di dalamnya. Sebaliknya ombak yang terdapat di daerah pantai, terutama di daerah pecahan ombak (breaker zone) mempunyai energi yang besar dan sangat berperan dalam pembentukan morfologi pantai, seperti menyeret sedimen (umumnya pasir dan kerikil) yang ada di dasar laut untuk ditumpahkan dalam bentuk gusung pasir (sand bar) (Dahuri, dkk, 1996). Adapun tujuan penelitian ini adalah untuk untuk Menganalisis arus dan gelombang perairan dengan prinsip kerja waves buoys di Gili Asahan Desa Batu Putih Kecamatan Sekotong Lombok Barat.

\section{B. METODE PENELITIAN}

\section{Lokasi Penelitian}

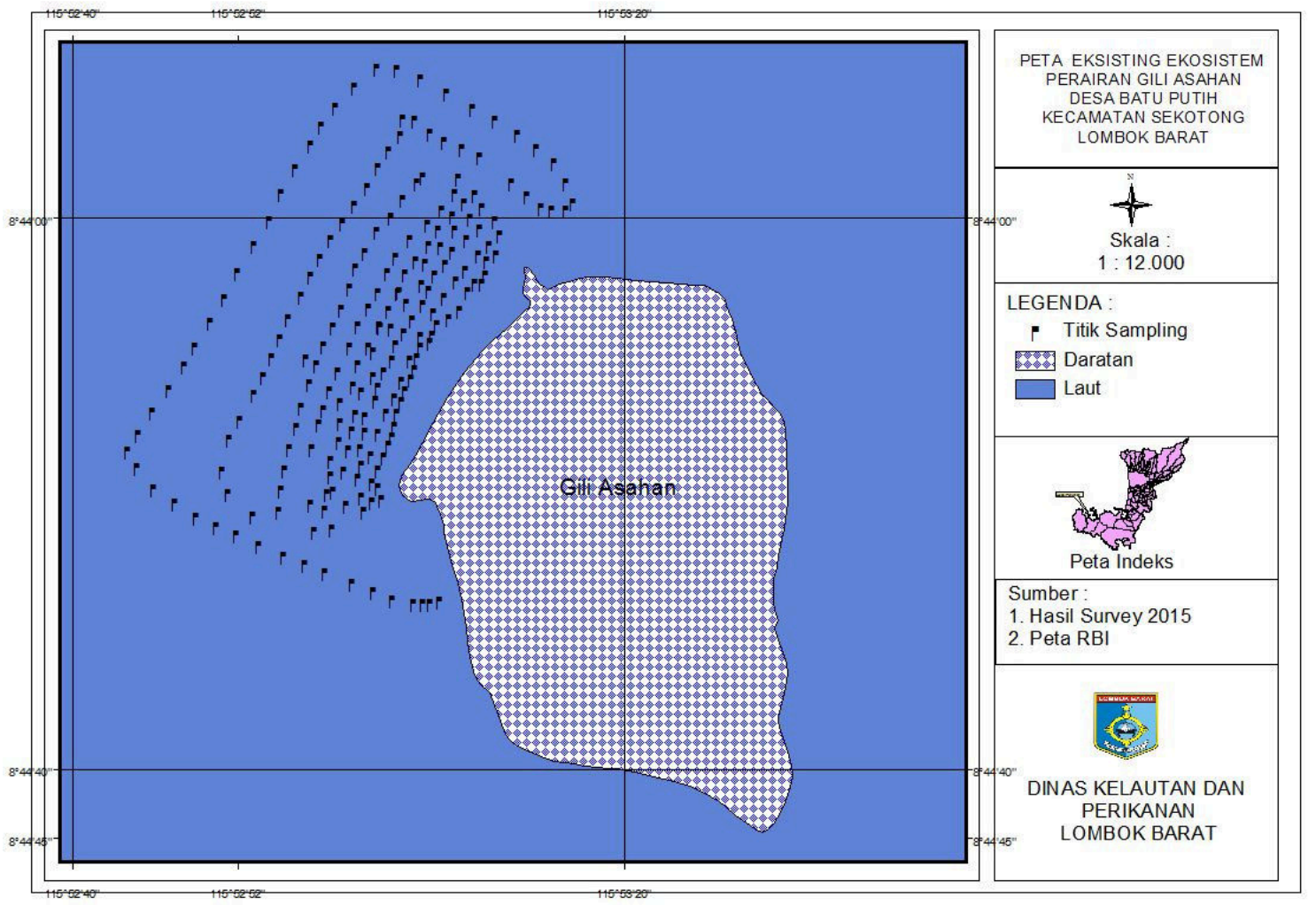

Gambar 1. Lokasi Penelitian 


\section{Alat dan Bahan}

Adapun peralatan yang digunakan pada penelitian ini meliputi :

1. Peralatan survei untuk pengambilan data :

a. Kapal motor sebagai alat transportasi.

b. Global Positioning System (GPS) untuk penentuan posisi pengambilan data.

c. Model 106 Lightweight Current Meter untuk Mengukur Gelombang, Arus, Suhu dan Tekanan secara otomatis.

d. Roll meter untuk mengukur jarak.

e. Stop Watch untuk mengukur waktu.

f. Alat tulis-menulis.

g. Kompas untuk mengukur arah arus dan gelombang.

2. Peralatan untuk analisis data :

a. Hardware : Komputer Personal dan Printer Inkjet.

b. Software: MS. Excel, MS. Word, Arc View 3.2 dan ArcGis 10.

\section{Prosedur Penelitian}

Metode Penelitian ini terdiri dari tahap persiapan atau observasi awal. Penentuan Stasiun Pengamatan, Pengambilan data, analisa data dan penyusunan laporan akhir.

\section{Tahap Persiapan}

Meliputi survey lapangan, untuk mengetahui kondisi lokasi penelitian. Disamping itu dilakukan pengumpulan data sekunder dan studi literatur yang berhubungan dengan penelitian

\section{Penentuan Stasiun Pengamatan}

Stasiun pengamatan ditentukan di lokasi berdasarkan kondisi perairan. Pengambilan data dipilih dengan koordinat yang ditentukan sebelumnya secara selektif dan sistematis dengan menggunakan GPS.

3. Pengambilan (pengumpulan) Data

\section{a. Pengukuran ombak}

Pengukuran tinggi, waktu dan arah gelombang dilakukan dengan menggunakan Model 106 Lightweight Current Meter, kompas dan alat tulis menulis. Pengukuran tinggi gelombang dilakukan secara otomatis membaca pergerakan naik (puncak) dan turun (lembah) permukaan laut pada alat Model 106 Lightweight Current Meter. Arah ombak diukur dengan mempergunakan kompas.

b. Pengukuran arus

Pengukuran arus dilakukan dengan menggunakan Model 106 Lightweight Current Meter. Pengukuran pergerakan arah arus dilakukan dengan menggunakan kompas, yakni dengan menentukan posisi titik Model 106 Lightweight Current Meter ketika dilepas waktu tertentu.

\section{Analisa Data}

Data yang diperoleh di lapangan digunakan untuk menghitung tinggi ombak rata-rata, tinggi ombak signifikan, periode rata-rata dan panjang ombak:

Tinggi ombak: $\quad H=$ puncak - lembah

Tinggi ombak rata-rata : $\bar{H}=\frac{H_{1}+H_{2}+\cdots+H_{N}}{N}$

Periode ombak: $T=\frac{t}{N}$

Panjang ombak: $\mathrm{L}=\mathrm{C} \times \mathrm{T}$

Kecepatan Gelombang : $C=\sqrt{ } g h$

Energi Gelombang : $E=\left(\rho \times g \times H_{1 / 3}^{2}\right) / 8$

$\left(\mathrm{N} / \mathrm{m}^{2}\right)$ (US, 19. Army 92)

di mana :

$\mathrm{t}$ adalah waktu (s)

$\mathrm{N}$ adalah jumlah pengamata

$h$ adalah Kedalaman (m)

$g$ adalah percepatan gravitasi $\left(\mathrm{m} / \mathrm{s}^{2}\right)$

$\rho$ adalah konstanta massa jenis air (1024 $\mathrm{kg} / \mathrm{m}^{2}$ )

\section{HASIL DAN PEMBAHASAN}

A. Arus

Hasil pengukuran arus sebelum belombang pecah menunjukkan bahwa arus pada lokasi kajian cenderung tenang dengan kisaran kecepatan anatar $0.00-0.63 \mathrm{~m} / \mathrm{s}$ dan rata-rata kecepatan arus berkisar $0.0046 \mathrm{~m} / \mathrm{s}$. Dari hasi pengukuran juga dapat dilihat bahwa dominan arah kecepatan arus menuju arah barat daya (gambar 3.3 kiri) dengan kecepatan arus dominan pada kecepatan $0.00-0.05$ (gambar 3.3 kanan) dengan frekuensi $96.3 \%$ dari keseluruhan data. 

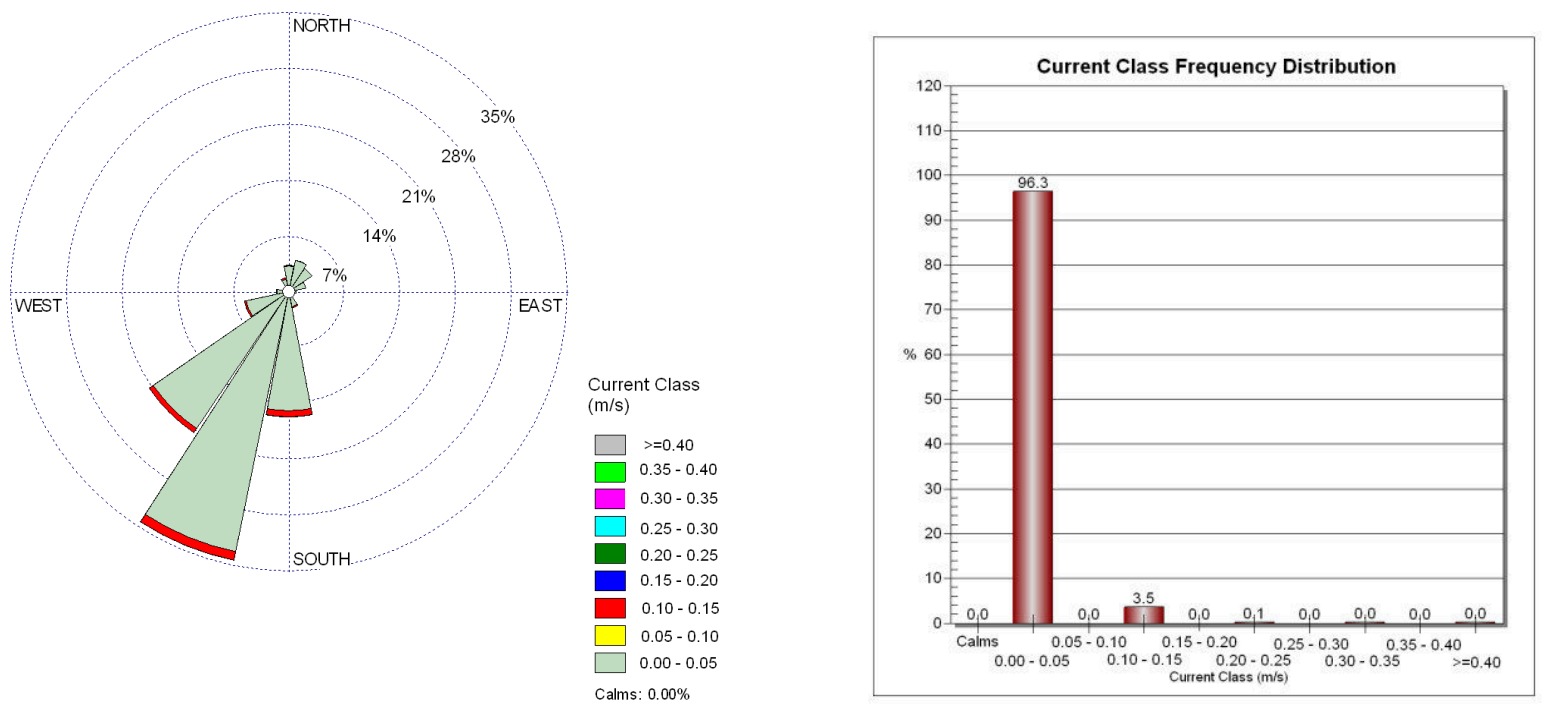

\section{Gambar 2. Mawar kecepatan Arus dan diagram kecepatan arus sebelum gelombang pecah}

Hasil pengukuran lebih detail tentang jumlah data dan distribusi frekuensi arus pada setiap kelas arah dan kelas kecepatan sebelum gelombang pecah di Gili Asahan dapat di lihat pada tabel 3.1 dan tabel 3.2. Dari tabel 3.1 terlihat kecepatan arus dominan pada kecepatan antara $0-0.05 \mathrm{~m} / \mathrm{s}$ dengan pada semua arah dengan data sebanyak 61350 (table 1) atau sebesar $96.3 \%$ (tabel 3.2), kemudian di ikuti oleh kecepatan arus antara $0.1-0.15,0.2$ $0.25,0.3-0.35 \mathrm{~m} / \mathrm{s}$, dan lebih dari atau sama dengan $0.4 \mathrm{~m} / \mathrm{s}$ masing masing sebanyak 2248 , 65,10 dan 5 data dengan frekuensi masingmasing $3.5 \%, 0.1,0,02$, dan $0.008 \%$. Dari tabel juga terlihat bahwa tidak ada data pada kelas kecepatan 0.05-0.1, 0.15-0.2, 0.25-0.3, dan 0.3-
$0.4 \mathrm{~m} / \mathrm{s}$ sehingga frequensi distribusinya juga menjadi 0 (tabel 3.2). Dari data kelas arah arus secara keseluruhan dapat terlihat bahwa arah arus dominan menuju Barat Daya condong selatan arah $191.25^{\circ}-213.75^{\circ}$ dengan data sebanyak 21830 (tabel 3.1) atau $34 \%$ (tabel 3.2). Selanjutnya kelas arah arus di ikuti arah $213.75^{\circ}-236.25^{\circ}$ (Barat Daya) dan $168.75^{\circ}$ $191.25^{\circ}$ (Selatan) masing-maisng sebesar 21 dan $16 \%$. Arah arus yang paling kecil berasa dari arah $101.25^{\circ}-123.75^{\circ}$ sebanyak 338 data atau $0.5 \%$. arah arus ini di duga karena arah orientasi pantai yang cenderung kearah barat daya ke Timur laut. 
Tabel 1. Jumlah data pada setiap kelas arah (Direction) dan kelas kecepatan arus (current class) Gili Asahan Sebelum Gelombang pecah

\begin{tabular}{|c|c|c|c|c|c|c|c|c|c|c|c|}
\hline \multirow{2}{*}{ No } & \multirow{2}{*}{ Directions } & \multicolumn{10}{|c|}{ Current Class $(\mathrm{m} / \mathrm{s})$} \\
\hline & & $0.0-0.05$ & $0.05-0.1$ & $0.1-0.15$ & $0.15-0.20$ & $0.2-0.25$ & $0.25-0.3$ & $0.3-0.35$ & $0.35-0.4$ & $>=0.4$ & Total \\
\hline 1 & $348.75-11.25$ & 2092 & 0 & $\begin{array}{r}67 \\
\end{array}$ & 0 & 1 & 0 & 0 & 0 & 0 & 2160 \\
\hline 2 & $11.25-33.75$ & 2601 & 0 & 26 & 0 & 0 & 0 & 0 & 0 & 0 & 2627 \\
\hline 3 & $33.75-56.25$ & 2280 & 0 & 4 & 0 & 0 & 0 & 0 & 0 & 0 & 2284 \\
\hline 4 & $56.25-78.75$ & 1448 & 0 & 9 & 0 & 0 & 0 & 0 & 0 & 0 & 1457 \\
\hline 5 & 78.75 - 101.25 & 652 & 0 & 19 & 0 & 0 & 0 & 0 & 0 & 0 & 671 \\
\hline 6 & $101.25-123.75$ & 308 & 0 & 27 & 0 & 2 & 0 & 1 & 0 & 0 & 338 \\
\hline 7 & $123.75-146.25$ & 347 & 0 & 31 & 0 & 5 & 0 & 0 & 0 & 0 & 383 \\
\hline 8 & $146.25-168.75$ & 1279 & 0 & 102 & 0 & 6 & 0 & 3 & 0 & 0 & 1390 \\
\hline 9 & $168.75-191.25$ & 9512 & 0 & 485 & 0 & 15 & 0 & 3 & 0 & 2 & 10017 \\
\hline 10 & $191.25-213.75$ & 21122 & 0 & 701 & 0 & 6 & 0 & 0 & 0 & 1 & 21830 \\
\hline 11 & $213.75-236.25$ & 13190 & 0 & 386 & 0 & 0 & 0 & 1 & 0 & 1 & 13578 \\
\hline 12 & $236.25-258.75$ & 3545 & 0 & 144 & 0 & 3 & 0 & 0 & 0 & 0 & 3692 \\
\hline 13 & $258.75-281.25$ & 977 & 0 & 49 & 0 & 5 & 0 & 0 & 0 & 0 & 1031 \\
\hline 14 & $281.25-303.75$ & 418 & 0 & 34 & 0 & 2 & 0 & 0 & 0 & 0 & 454 \\
\hline 15 & $303.75-326.25$ & 487 & 0 & 59 & 0 & 8 & 0 & 2 & 0 & 1 & 557 \\
\hline 16 & $326.25-348.75$ & 1092 & 0 & 105 & 0 & 12 & 0 & 0 & 0 & 0 & 1209 \\
\hline & Sub-Total & 61350 & 0 & 2248 & 0 & 65 & 0 & 10 & 0 & 5 & 63678 \\
\hline & Calms & & & & & & & & & & 0 \\
\hline & Missing/Incomplete & & & & & & & & & & 35 \\
\hline & Total & & & & & & & & & & 63713 \\
\hline
\end{tabular}

Tabel 2. Distribusi pada setiap kelas arah (Direction) dan kelas kecepatan arus (current class) Gili Asahan Sebelum Gelombang pecah

\begin{tabular}{|c|c|c|c|c|c|c|c|c|c|c|c|}
\hline \multirow{2}{*}{ No } & \multirow{2}{*}{ Directions } & \multicolumn{10}{|c|}{ Current Class (m/s) } \\
\hline & & $0.0-0.05$ & $0.05-0.1$ & $0.1-0.15$ & $0.15-0.20$ & $0.2-0.25$ & $0.25-0.3$ & $0.3-0.35$ & $0.35-0.4$ & $>=0.4$ & Total \\
\hline 1 & $348.75-11.25$ & 0.03285 & 0 & 0.00105 & 0 & 0.00002 & 0 & 0 & $\begin{array}{r}0 \\
\end{array}$ & 0 & 0.0339 \\
\hline 2 & $11.25-33.75$ & 0.04085 & 0 & 0.00041 & 0 & 0 & 0 & 0 & 0 & 0 & 0.04123 \\
\hline 3 & $33.75-56.25$ & 0.03581 & 0 & 0.00006 & 0 & 0 & 0 & 0 & 0 & 0 & 0.03585 \\
\hline 4 & $56.25-78.75$ & 0.02274 & 0 & 0.00014 & 0 & 0 & 0 & 0 & 0 & 0 & 0.02287 \\
\hline 5 & $78.75-101.25$ & 0.01024 & 0 & 0.0003 & 0 & 0 & 0 & 0 & 0 & 0 & 0.01053 \\
\hline 6 & $101.25-123.75$ & 0.00484 & 0 & 0.00042 & 0 & 0.00003 & 0 & 0.00002 & 0 & 0 & 0.00531 \\
\hline 7 & $123.75-146.25$ & 0.00545 & 0 & 0.00049 & 0 & 0.00008 & 0 & 0 & 0 & 0 & 0.00601 \\
\hline 8 & $146.25-168.75$ & 0.02009 & 0 & 0.0016 & 0 & 0.00009 & 0 & 0.00005 & 0 & 0 & 0.02182 \\
\hline 9 & $168.75-191.25$ & 0.14938 & 0 & 0.00762 & 0 & 0.00024 & 0 & 0.00005 & 0 & 0.00003 & 0.15722 \\
\hline 10 & $191.25-213.75$ & 0.3317 & 0 & 0.01101 & 0 & 0.00009 & 0 & 0 & 0 & 0.00002 & 0.34263 \\
\hline 11 & $213.75-236.25$ & 0.20714 & 0 & 0.00606 & 0 & 0 & 0 & 0.00002 & 0 & 0.00002 & 0.21311 \\
\hline 12 & $236.25-258.75$ & 0.05567 & 0 & 0.00226 & 0 & 0.00005 & 0 & 0 & 0 & 0 & 0.05795 \\
\hline 13 & $258.75-281.25$ & 0.01534 & 0 & 0.00077 & 0 & 0.00008 & 0 & 0 & 0 & 0 & 0.01618 \\
\hline 14 & $281.25-303.75$ & 0.00656 & 0 & 0.00053 & 0 & 0.00003 & 0 & $\overline{0}$ & $\overline{0}$ & 0 & 0.00713 \\
\hline 15 & $303.75-326.25$ & 0.00765 & 0 & 0.00093 & 0 & 0.00013 & 0 & 0.00003 & 0 & 0.00002 & 0.00874 \\
\hline 16 & $326.25-348.75$ & 0.01715 & 0 & 0.00165 & 0 & 0.00019 & 0 & 0 & 0 & 0 & 0.01898 \\
\hline & Sub-Total & 0.96291 & 0 & 0.03528 & 0 & 0.00102 & 0 & 0.00016 & 0 & 0.00008 & 0.99945 \\
\hline & Calms & & & & & & & & & & 0 \\
\hline & Missing/Incomplete & & & & & & & & & & 0.00055 \\
\hline & Total & & & & & & & & & & 1 \\
\hline
\end{tabular}

Hasil pengukuran arus pada lokasi kajian setelah gelombang pecah menunjukkan bahwa arus memiliki kecepatan antara $0-0.56$ $\mathrm{m} / \mathrm{s}$ dengan kecepatan rata-rata $0.023 \mathrm{~m} / \mathrm{s}$. Dari hasil pengukuran di dapatkan bahwa arus setelah gelombang pecah juga dominan kea rah Barat Daya (gambar 3.4 kiri), hampir sama dengan arah arus sebelum gelombang pecah. Jika di lihat dari kecepatan arus secara menyeluruh didapatkan bahwa kecepatan arus setelah gelombang pecah sebanyak 10.7\% memiliki kecepatan $0.10-0.15 \mathrm{~m} / \mathrm{s}$, kecepatan arus ini lebih besar dibandingkan dengan sebelum gelombang pecah yang hanya mencapat $3.5 \%$ pada kecepatan yang sama. Selain itu kecepatan arus setelah gelombang pecah cenderung lebih besar dibandingkan dengan kecepatan arus sebelum gelombang pecah, hal ini terlihat dari distribusi frequensi arus kecepatan $0.00-0.05 \mathrm{~m} / \mathrm{s}$ yang hanya mencapai 83.9\% (gambar 3.4 kanan), lebih kecil dibandingkan kecepatan arus pada distribusi frequensi arus kecepartan yang sama. Hal ini di duga karena tambaha kecepatan arus berasal dari pecahnya gelombang pada tempat sebelum dipasang alat.

Namun secara keseluruhan, arus sebelum dan sesudah gelombang pecah 
cenderung dalam kondisi yang sangat tenang, hal ini di duga karena kondisi pengukuran yang masih dalam kondisi musim timur dimana pada saat musim timur daerah ini cenderung

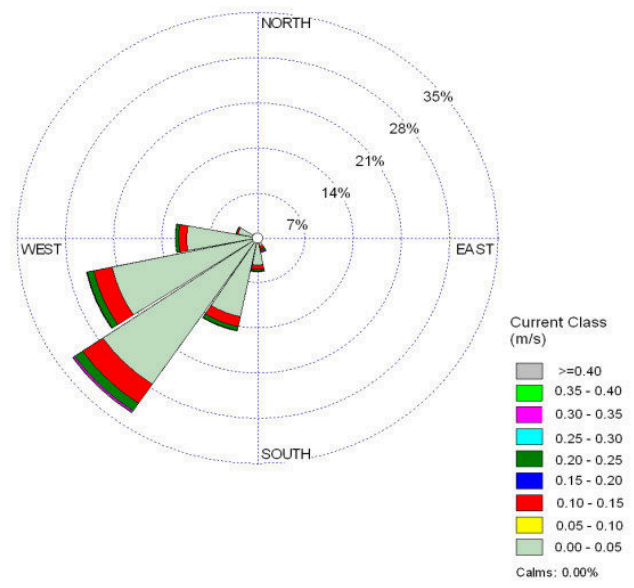

mendapat tiupan angin dari arah daratan ke lautan sehingga arus yang terbentuk juga sangat lemah.

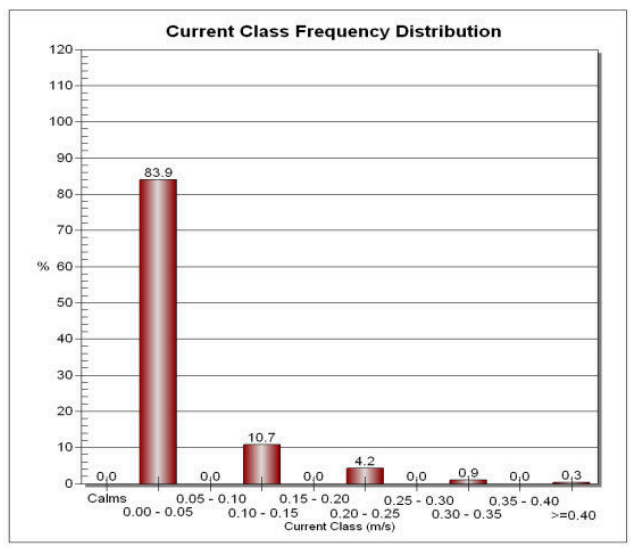

\section{Gambar 3. Mawar kecepatan Arus dan diagram kecepatan arus setelah gelombang pecah}

Hasil pengukuran pada daerah sesudah gelombang pecah di daerah Gili Asahan secara lebih detail dapat dilihat pada tabel 3.3 dan 3.4 dengan jumlah data dan distribusi frekuensi arus pada setiap kelas arah dan kelas kecepatan. Secara keseluruhan, dari tabel dapat terlihat bahwa kecepatan arus sesudah gelombang pecah lebih besar dibandingkan dengan sebelum gelombang pecah. Dari tabel 3.3 juga terlihat pola datanya hampir sama dengan tabel 3.1 dimana kecepatan arus dominan pada kecepatan antara $0-0.05 \mathrm{~m} / \mathrm{s}$ dengan pada semua arah dengan data sebanyak 53797 atau sebesar $83.8 \%$ (tabel 3.4), kemudian di ikuti oleh kecepatan arus antara $0.1-0.15,0.2$ $0.25,0.3-0.35 \mathrm{~m} / \mathrm{s}$, dan lebih dari atau sama dengan $0.4 \mathrm{~m} / \mathrm{s}$ masing masing sebanyak 6852 ,
2667, 579 dan 198 data dengan frekuensi masing-masing 10.6, 4.1, 0.9, dan $0.03 \%$. Dari tabel juga terlihat bahwa tidak ada data pada kelas kecepatan 0.05-0.1, 0.15-0.2, 0.25-0.3, dan $0.3-0.4 \mathrm{~m} / \mathrm{s}$ sehingga frequensi distribusinya juga menjadi 0 (tabel 3.4), hal ini sangat mirip dengan pola yang ada pada tabel 3.2. Dari data kelas arah arus secara keseluruhan dapat terlihat bahwa arah arus dominan menuju arah Barat Daya $\left(213.75^{\circ}-236.25^{\circ}\right)$ dengan data sebanyak 20934 (tabel 3.1) atau $32.6 \%$ (tabel 3.2). Selanjutnya kelas arah arus di ikuti arah 236.25 - 258.75 dan 191.25 - 213.75 masingmaisng sebesar 25.4 dan $14.7 \%$. Arah arus yang paling kecil berasa dari arah $101.25^{\circ}$ $123.75^{\circ}$ sebanyak 123 data atau $0.2 \%$. 
Tabel 3. Jumlah data pada setiap kelas arah (Direction) dan kelas kecepatan arus (current class) Gili Asahan Setelah Gelombang pecah

\begin{tabular}{|c|c|c|c|c|c|c|c|c|c|c|c|}
\hline \multirow{2}{*}{ No } & \multirow{2}{*}{ Directions } & \multicolumn{10}{|c|}{ Current Class (m/s) } \\
\hline & & $0.0-0.05$ & $0.05-0.1$ & $0.1-0.15$ & $0.15-0.20$ & $0.2-0.25$ & $0.25-0.3$ & $0.3-0.35$ & $0.35-0.4$ & $>=0.4$ & Total \\
\hline 1 & $348.75-11.25$ & 246 & \begin{tabular}{r|}
0 \\
\end{tabular} & 14 & $\begin{array}{r}0 \\
\end{array}$ & 0 & 0 & 1 & $\begin{array}{r}0 \\
\end{array}$ & 0 & 261 \\
\hline 2 & $11.25-33.75$ & 275 & 0 & 5 & 0 & 1 & 0 & 0 & 0 & 0 & 281 \\
\hline 3 & $33.75-56.25$ & 276 & 0 & 6 & 0 & 0 & 0 & 0 & 0 & 0 & 282 \\
\hline 4 & $56.25-78.75$ & 162 & 0 & 10 & 0 & 3 & 0 & 0 & 0 & 0 & 175 \\
\hline 5 & 78.75 - 101.25 & 138 & 0 & 13 & 0 & 3 & 0 & 2 & 0 & 0 & 156 \\
\hline 6 & $101.25-123.75$ & 92 & 0 & 16 & 0 & 9 & 0 & 5 & 0 & 1 & 123 \\
\hline 7 & $123.75-146.25$ & 174 & 0 & 43 & 0 & 57 & 0 & 58 & 0 & 30 & 362 \\
\hline 8 & $146.25-168.75$ & 884 & 0 & 310 & 0 & 175 & 0 & 128 & 0 & 56 & 1553 \\
\hline 9 & $168.75-191.25$ & 2736 & 0 & 445 & 0 & 162 & 0 & 61 & 0 & 14 & 3418 \\
\hline 10 & $191.25-213.75$ & 8002 & 0 & 1007 & 0 & 391 & 0 & 51 & 0 & 10 & 9461 \\
\hline 11 & $213.75-236.25$ & 17518 & 0 & 2277 & 0 & 904 & 0 & 168 & 0 & 67 & 20934 \\
\hline 12 & $236.25-258.75$ & 13872 & 0 & 1744 & 0 & 608 & 0 & 70 & 0 & 17 & 16311 \\
\hline 13 & $258.75-281.25$ & 6655 & 0 & 742 & 0 & 281 & 0 & 27 & 0 & 2 & 7707 \\
\hline 14 & $281.25-303.75$ & 1920 & 0 & 146 & 0 & 50 & 0 & 4 & 0 & 0 & 2120 \\
\hline 15 & $303.75-326.25$ & 546 & 0 & 49 & 0 & 15 & 0 & 4 & 0 & 1 & 615 \\
\hline 16 & $326.25-348.75$ & 301 & 0 & 25 & 0 & 8 & 0 & 0 & 0 & 0 & 334 \\
\hline & Sub-Total & 53797 & 0 & 6852 & 0 & 2667 & 0 & 579 & 0 & 198 & 64093 \\
\hline & Calms & & & & & & & & & & 0 \\
\hline & Missing/Incomplete & & & & & & & & & & 37 \\
\hline & Total & & & & & & & & & & 64130 \\
\hline
\end{tabular}

Tabel 4. Distribusi pada setiap kelas arah (Direction) dan kelas kecepatan arus (current class) Gili Asahan Setelah Gelombang pecah

\begin{tabular}{|c|c|c|c|c|c|c|c|c|c|c|c|}
\hline \multirow{2}{*}{ No } & \multirow{2}{*}{ Directions } & \multicolumn{10}{|c|}{ Current Class (m/s) } \\
\hline & & $0.0-0.05$ & $0.05-0.1$ & $0.1-0.15$ & $0.15-0.20$ & $0.2-0.25$ & \begin{tabular}{|l|}
$0.25-0.3$ \\
\end{tabular} & $0.3-0.35$ & $0.35-0.4$ & $>=0.4$ & Total \\
\hline 1 & $348.75-11.25$ & 0.00384 & 0 & 0.00022 & 0 & 0 & 0 & 0.00002 & 0 & 0 & 0.00407 \\
\hline 2 & $11.25-33.75$ & 0.00429 & 0 & 0.00008 & 0 & 0.00002 & 0 & 0 & 0 & 0 & 0.00438 \\
\hline 3 & $33.75-56.25$ & 0.00431 & 0 & 0.00009 & 0 & 0 & 0 & 0 & 0 & 0 & 0.0044 \\
\hline 4 & $56.25-78.75$ & 0.00253 & 0 & 0.00016 & 0 & 0.00005 & 0 & 0 & 0 & 0 & 0.00273 \\
\hline 5 & $78.75-101.25$ & 0.00215 & 0 & 0.0002 & 0 & 0.00005 & 0 & 0.00003 & 0 & 0 & 0.00243 \\
\hline 6 & $101.25-123.75$ & 0.00144 & 0 & 0.00025 & 0 & 0.00014 & 0 & 0.00008 & 0 & 0.00002 & 0.00192 \\
\hline 7 & $123.75-146.25$ & 0.00271 & 0 & 0.00067 & 0 & 0.00089 & 0 & 0.0009 & 0 & 0.00047 & 0.00564 \\
\hline 8 & $146.25-168.75$ & 0.01379 & 0 & 0.00484 & 0 & 0.00273 & 0 & 0.002 & 0 & 0.00087 & 0.02422 \\
\hline 9 & $168.75-191.25$ & 0.04269 & 0 & 0.00694 & 0 & 0.00253 & 0 & 0.00095 & 0 & 0.00022 & 0.0533 \\
\hline 10 & $191.25-213.75$ & 0.12485 & 0 & 0.01571 & 0 & 0.0061 & 0 & 0.0008 & 0 & 0.00016 & 0.14753 \\
\hline 11 & $213.75-236.25$ & 0.27332 & 0 & 0.03553 & 0 & 0.0141 & 0 & 0.00262 & 0 & 0.00105 & 0.32643 \\
\hline 12 & $236.25-258.75$ & 0.21644 & 0 & 0.02721 & 0 & 0.00949 & 0 & 0.00109 & 0 & 0.00027 & 0.25434 \\
\hline 13 & $258.75-281.25$ & 0.10383 & 0 & 0.01158 & 0 & 0.00438 & 0 & 0.00042 & 0 & 0.00003 & 0.12018 \\
\hline 14 & $281.25-303.75$ & 0.02996 & 0 & 0.00228 & 0 & 0.00078 & 0 & 0.00006 & 0 & 0 & 0.03306 \\
\hline 15 & $303.75-326.25$ & 0.00852 & 0 & 0.00076 & 0 & 0.00023 & 0 & 0.00006 & 0 & 0.00002 & 0.00959 \\
\hline 16 & $326.25-348.75$ & 0.0047 & 0 & 0.00039 & 0 & 0.00012 & 0 & 0 & 0 & 0 & 0.00521 \\
\hline & Sub-Total & 0.83887 & 0 & 0.10685 & 0 & 0.04159 & 0 & 0.00903 & 0 & 0.00309 & 0.99942 \\
\hline & Calms & & & & & & & & & & 0 \\
\hline & Missing/Incomplete & & & & & & & & & & 0.00058 \\
\hline & Total & & & & & & & & & & 1 \\
\hline
\end{tabular}

Hasil analisa data lapangan pada pengukuran arus menunjukkan bahwa kecepatan arus ratarata pada perairan di gili Asahan adalah 0.0045 $\mathrm{m} /$ det (sebelum ombak pecah) dan $0.0228 \mathrm{~m} / \mathrm{det}$ (setelah ombak pecah) dengan arah yang relatif sama yaitu arah barat daya condong arah selatan atau sejajar dengan pantai. Kecepatan arus berkisar antara $0-0,63 \mathrm{~m} /$ det pada titik sebelum ombak pecah dan $0-0.557 \mathrm{~m} / \mathrm{det}$ pada titik setelah ombak pecah. Data ini menunjukkan bahwa kecepatan arus di lokasi dikategorikan memiliki kecepatan arus lemah hingga sedang, hal ini sesuai dengan pendapat Djurdjani (1998) bahwa kecepatan arus dikategorikan lemah jika kecepatannya $<0,4 \mathrm{~m} / \mathrm{det}$, Sedang jika kecepatannya $0,4-1 \mathrm{~m} /$ det dan Kuat jika kecepatannya $>1 \mathrm{~m} /$ det.

Kategori arus lemah hingga sedang di lokasi sangat berhubungan erat dengan musim angin timur. Musim angin timur merupakan musim yang menyebabkan perairan agak tenang dilokasi khusus dan wilayah indonesia pada umumnya disamping itu, musim ini merupakan musim kering (kemarau) di Indonesia dikarenakan angin yang bertiup saat ini adalah angin yang bergerak dari benoa Australia ke benoa Asia yang memiliki kelembaban udara yang rendah (udara kering). Oleh karena itu, untuk mendapatkan data arus yang representatif diperlukan pengukuran pada 
musim yang berbeda (musim angin barat) supaya gambaran kondisi perairan dapat dijadikan acuan dalam pengambilan keputusan untuk pengelolaan potensi sumberdaya lautan secara terpadu.

\section{B. Gelombang}

Hasil analisis pengukuran gelombang didapatkan bahwa tinggi gelombang signifikan $\left(\mathrm{H}_{1 / 3}\right)$ pada lokasi penelitian adalah $0.019 \mathrm{~m}$ pada titik sebelum ombak pecah dan $0.0072 \mathrm{~m}$ pada titik setelah ombak pecah, dengan demikian keadaan gelombang signifikan dilokasi dikategrikan tenang hal ini didukung oleh pernyataan Djurdjani (1998) yang mengatakan bahwa Gelombang dikategorikan tenang jika tingginya $<0,20 \mathrm{~m}$, Sedang jika tingginya 0,2 $0,50 \mathrm{~m}$, dan besar jika tingginya $>0,50$. Adapun kecepatan gelombang sebelum dan sesudah ombak pecah pada musim angin timur dan barat masing-masing $5,48 \mathrm{~m} / \mathrm{s}, 2,74 \mathrm{~m} / \mathrm{s}$ dan $5,48 \mathrm{~m} / \mathrm{s}$ hal ini menunjukkan bahwa semakin mendekati pantai maka kecepatan gelombang semakin melemah seiring dengan kedalaman perairan yang semakin dangkal, sedangkan energi gelombang sebelum dan sesudah ombak pecah pada musim angin timur dan barat masingmasing adalah $0,460 \mathrm{~N} / \mathrm{m}^{2}, 0,066 \mathrm{~N} / \mathrm{m}^{2}$ dan $1965,172 \mathrm{~N} / \mathrm{m}^{2}$ yang menunjukkan adalah fluktuasi energi gelombang yang menghempas pantai sebagaimana tertera pada tabel 3.5. Fluktuasi energi gelombang sangat dipengaruhi oleh faktor musim. Pada musim angin timur menunjukkan bahwa energy gelombang yang menghempas pantai sangat lemah karena pada musim ini angin yang bertiup sangat lemah sehingga sehingga gelombang yang terbentuk akibat tenaga angin sangat kecil, namun sebaliknya, ketika musim barat tinggi ombak signifikan yang terbentuk dikategorikan besar karena pada musim ini angin bertiup sangat besar yang berimplikasi terhadap besarnya energy gelombang yang menghempas pantai.

Secara umum energi gelombang yang menghempas pantai sangat dipengaruhi oleh ekosistem dasar perairan, dalam hal ini ekosistem terumbu karang dan padang lamun. Keberadaan Terumbu karang dan padang lamun dilokasi memberikan pengaruh terhadap besarkecilnya abrasi yang terjadi akibat energy gelombang di pantai. Berdasarkan hasil survey dilapangan menunjukkan bahwa kondisi ekosistem terumbu karang dan padang lamun masih dalam keadaan baik sehingga memberikan pengaruh yang signifikan terhadap kestabilan pantai dan dapat mencegah terjadinya abrasi.

Tabel 5 Hasil analisa parameter gelombang

\begin{tabular}{|c|c|c|c|c|}
\hline \multirow[b]{2}{*}{ No } & \multirow[b]{2}{*}{ Parameter Gelombang } & \multicolumn{3}{|c|}{ Stasiun Pengukuran } \\
\hline & & $\begin{array}{c}\text { Sebelum Ombak } \\
\text { Pecah }\end{array}$ & $\begin{array}{c}\text { Setelah } \\
\text { Ombak Pecah }\end{array}$ & Angin Barat \\
\hline 1 & 2 & 3 & 4 & 5 \\
\hline 1 & $\begin{array}{ll}\begin{array}{l}\text { Koordinat } \\
\text { degree) }\end{array} & \text { (decimals } \\
\end{array}$ & $\begin{array}{c}8,73278 \mathrm{~S} \\
115,88249 \mathrm{E}\end{array}$ & $\begin{array}{c}8,73309 \mathrm{~S}, \\
115,88400 \mathrm{E}\end{array}$ & $\begin{array}{r}8,73278 \mathrm{~S}, \\
115,88249 \mathrm{E}\end{array}$ \\
\hline 2 & $\begin{array}{l}\text { Tinggi Ombak Siginifan } \\
\left(\mathrm{H}_{1 / 3}\right)(\mathrm{m})\end{array}$ & 0,019 & 0,0072 & 1,239 \\
\hline 3 & $\begin{array}{l}\text { Periode Gelombang ( } \mathrm{T}) \\
\text { (s) }\end{array}$ & 1,017 & 1,0104 & 9,538 \\
\hline 4 & $\begin{array}{l}\text { Periode Gelombang } \\
\text { Signifikan }\left(T_{1 / 3}\right)(s)\end{array}$ & 1,119 & 1,1115 & 10,491 \\
\hline 5 & $\begin{array}{l}\text { Kecepatan Gelombang } \\
\text { (C) }(\mathrm{m} / \mathrm{s})\end{array}$ & 5,48 & 2,74 & 5,477 \\
\hline 6 & $\begin{array}{l}\text { Panjang Gelombang (L) } \\
(\mathrm{m})\end{array}$ & 5,57 & 2,767 & 57,464 \\
\hline 7 & $\begin{array}{l}\text { Energi Gelombang (E) } \\
\left(\mathrm{N} / \mathrm{M}^{2}\right)\end{array}$ & 0,460 & 0,066 & 1965,172 \\
\hline
\end{tabular}




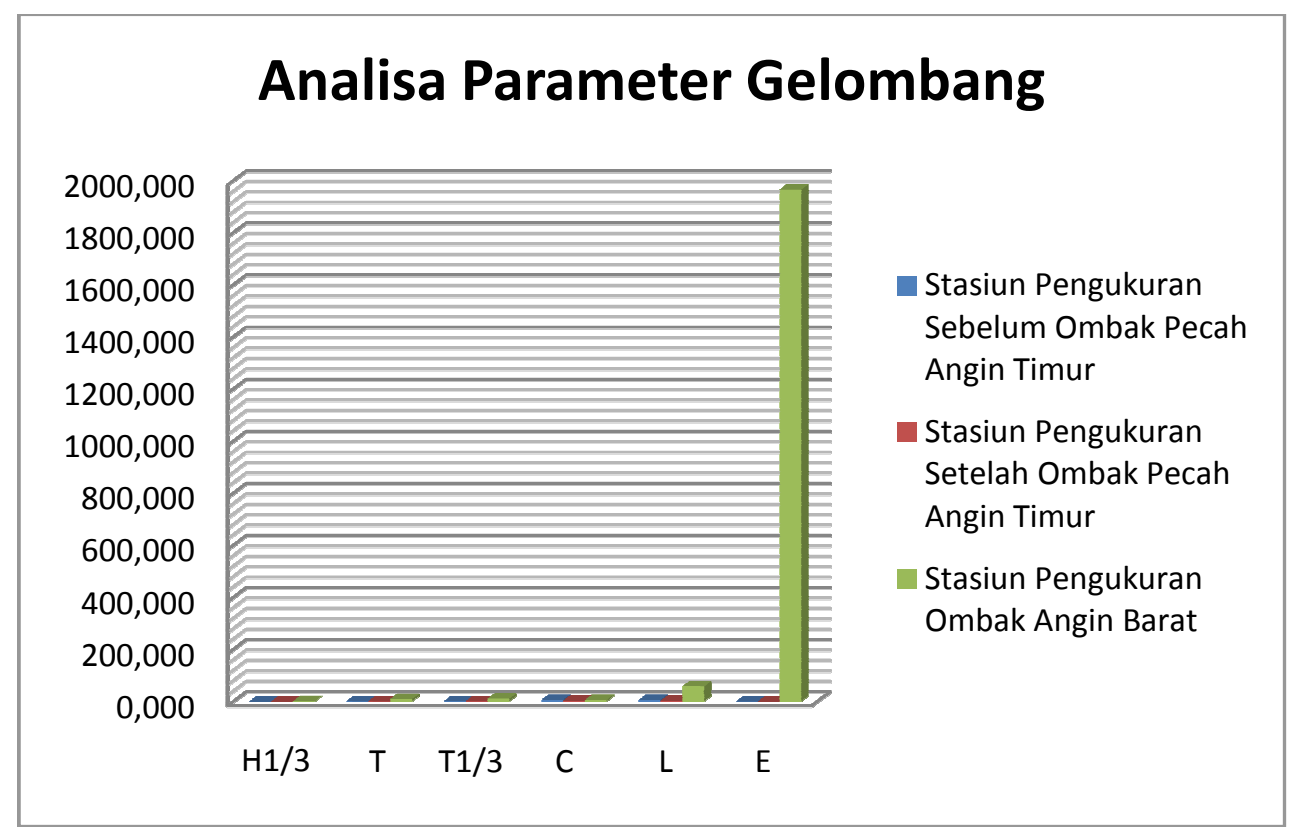

\section{Gambar 4. Analisa Parameter Gelombang}

Kategori gelombang yang tenang di lokasi sangat berhubungan erat dengan musim angin timur. Musim angin timur merupakan musim yang menyebabkan perairan agak tenang dilokasi khusus dan wilayah indonesia pada umumnya disamping itu, musim ini merupakan musim kering (kemarau) di Indonesia dikarenakan angin yang bertiup saat ini adalah angin yang bergerak dari benoa Australia ke benoa Asia yang memiliki kelembaban udara yang rendah (udara kering). Kondisi angin yang bertiup di permukaan perairan akan berpengaruh terhadap besar dan kecilnya gelombang yang terbentuk hal ini sesuai dengan pendapatnya Hutabarat dan Evans (1984) bahwa tipe angin yang mempengaruhi besar dan kecilnya gelombang yang terbentuk adalah tergantung kecepatan angin bertiup dipermukaan, sumber dimana angin sedang bertiup dan jarak Fetch (Fetch lenght).

Ketika musim angin timur, angin bertiup dari perairan samudera Hindia melewati permukan perairan Indonesia menuju samudera Pasifik dengan kecepatan yang rendah dengan kelembaban yang rendah yang mempengaruhi bentuk gelombang yang terjadi di perairan Indonesia dengan demikian, gelombang yang terbentuk di perairan Indonesia pada umumnya dan lokasi penelitian pada khususnya akan tenang. Oleh karena itu, untuk mendapatkan data arus yang representatif diperlukan pengukuran pada musim yang berbeda (musim angin barat) supaya gambaran kondisi perairan dapat dijadikan acuan dalam pengambilan keputusan untuk pengelolaan potensi sumberdaya lautan secara terpadu.

Hal tersebut menurut Carter (1988), jika suatu muka barisan gelombang datang dan membentuk sudut miring terhadap garis pantai yang mempunyai kemiringan dasar landai dengan kontur-kontur kedalaman sejajar dengan pantai , maka muka gelombang akan berubah arah dan cenderung menjadi sejajar dengan garis pantai atau mengalami proses pembiasan. Selanjutnya arah perambatan gelombang berubah dengan berkurangnya kedalaman, sehingga dapat diamati bahwa muka gelombang cenderung sejajar dengan kedalaman. Hal ini disebabkan perubahan gelombang yang mengakibatkan perubahan kecepatan fasa gelombang. Bila keadaan pantai landai, ada kemungkinan bahwa gelombang tersebut tidak pecah tetapi pemantulan gelombang (refleksi).

\section{PENUTUP}

\section{A. SIMPULAN}

1. Tinggi gelombang signifikan $\left(\mathrm{H}_{1 / 3}\right)$ pada lokasi penelitian sebelum dan sesudah ombak pecah masing-masing adalah $0.019 \mathrm{~m}$ dan $0.0072 \mathrm{~m}$ pada titik setelah ombak pecah, dengan 
demikian keadaan gelombang signifikan dilokasi dikategrikan tenang

2. Kecepatan arus rata-rata sebelum dan sesudah ombak pecah masing-masing adalah $0.0045 \mathrm{~m} / \mathrm{det}$ dan $0.0228 \mathrm{~m} / \mathrm{det}$ yang menunjukkan arus cenderung dalam kondisi yang sangat tenang, hal ini di duga karena kondisi pengukuran yang masih dalam kondisi musim timur.

\section{B. SARAN}

1. Untuk meningkatkan nilai penting dari suatu lahan pesisir dan pulau-pulau kecil sebaiknya dalam pemanfaatan dan pengembangannya harus memperhatikan faktor-faktor lingkungan yang menjadi daya dukungnya (carring capacity).

2. Perlunya perhatian khusus terkait faktor penentu keberhasilan pengembangan dan pemanfaatan potensi lahan seperti bentang alam (landscape) serta parameter yang lain seperti karakteristik oceanografi dan substrat dasar perairan sehingga membantu dalam perencanaan pemanfaatan tata ruang wilayah pesisir dan pulau-pulau kecil berbasis lingkungan sehingga nantinya dapat dikembangkan demi kebutuhan dan kesejateraan masyarakat pesisir sekitarnya,

3. Pemerintah setempat harus memiliki acuan yang jelas dalam menentukan rencana penggunaan lahan wilayah pesisir supaya potensi yang ada termanfaatkan secara optimal demi kesejahteraan masyarakat serta mengurangi konflik kepentingan antar masyarakat,

4. Pemerintah setempat bersama pemerintah pusat harus menindaklanjuti rencana tata ruang wilayah pesisir selatan Lombok Barat sesuai peruntukkannya sehingga dapat meningkatkan pendapatan asli daerah yang berasal dari pemberdayaan wilayah pesisir dan lautan secara terpadu.

5. Hendaknya pemerintah daerah mendukung program pusat dengan berbasis pada masyarakat pesisir supaya program kelautan dan perikanan berjalan sesuai dengan target yang telah ditetapkan pada masing-masing program. $\begin{array}{lr}\text { 6. Hendaknya } & \text { pemerintah } \\ \text { mempertimbangkan rencana }\end{array}$ pembangunan Hotel di Wilayah perairan dangkal gili Asahan karena kondisi terumbu karang yang masih baik.

7. Pemerintah juga harus mempertimbangkan rencana pembangunan hotel Jika ditinjau dari besarnya energi gelombang yang terjadi pada musim barat karena dikhawatirkan akan terjadi abrasi pantai.

\section{DAFTAR PUSTAKA}

Dahuri, R., J. Rais, S. P. Ginting dan M. J. Sitepu. 2004. Pengelolaan Sumber Daya Wilayah Pesisir dan Lautan Secara Terpadu. Pradnya Paramita. Jakarta

Djurdjani. 1998. Konsep Pemetaan PUCPIC. Fakultas Geografi UGM. Yogyakarta

Djamaluddin, R. dan W.W. Pandoe, 1996, Laser Airbone Depth Sounder, Direktorat Teknologi Inventarisasi Sumberdaya Alam BPPT, Jakarta

Hutabarat,S. dan S, M. Evans. 1984. Pengantar Oseanografi. Universitas Indonesia. Jakarta.

US. Army, 1992, Shore Protection Manual 1 and 2. US Government Printing Office. Washington DC 